\title{
Effects of Kefir as a Probiotic Source on the Performance and Health of Young Dairy Calves
}

\section{Sema Satık, Mevlüt Günal*}

Department of Animal Science, Faculty of Agriculture, Süleyman Demirel University, 32200 Isparta, Turkey

\begin{tabular}{l}
\hline A R T I C L E I N F O \\
\hline Research Article \\
Received 08 September 2016 \\
Accepted 03 January 2017 \\
\hline Keywords: \\
Probiotic \\
Kefir \\
Health \\
Calves \\
Performance
\end{tabular}
\begin{abstract}
A B S T R A C T
The aim of this study was to investigate the effect of kefir as a probiotic on the performance and health status of calves. Thirty Holstein female calves with 3-day-old were randomly allocated to three treatment groups: Control (without any probiotic), probiotic (a commercial probiotic mixture- $3 \mathrm{~g} / \mathrm{d} / \mathrm{calf}$ bacteria-based and $2 \mathrm{~g} / \mathrm{d} /$ calf yeastbased) and kefir $(20 \mathrm{ml} / \mathrm{d} / \mathrm{calf})$. The calves were weaned at 56 days of age. The experiment was performed in 70 days. Treatment had no effect $(\mathrm{P}>0.05)$ on weaning and final body weight and starter intake. Although differences in weight gain were not significant $(\mathrm{P}>0.05)$, there were trend to increase by probiotic treatments during $0-14$ days. Probiotic treatments tended to have a positive effect on the population of the fecal lactic acid bacteria at 14 days. The results of the study indicated that kefir as a natural probiotic in calf nutrition may be beneficial during the first weeks of life.
\end{abstract}

*Corresponding Author:

E-mail: mevlutgunal@sdu.edu.tr

\section{Introduction}

In intensive rearing systems, calves are susceptible to enteric bacterial imbalance and usually suffer from diarrhea and respiratory diseases, leading to inefficient digestion and absorption of nutrients and consequently retarded growth (Radostits, 1975). Antibiotics have been successfully used in reducing these problems also to obtain economic benefits in terms of improved calves performance and reduced medication costs. However, the use of antibiotics in animal production has been queried due to the potential of appearance of residues in animal products (Russell and Houlihan, 2003). Recently, some additives have been increasingly evaluated to replace or facilitate reductions in the use of antibiotics. Probiotics are examples of these additives (Frizzo et al., 2010). Probiotics are live microbial feed supplements which beneficially affect the host animal by improving its microbial balance (Fuller, 1989). Probiotics have been shown to have many function, including protecting young animal against enteropathic disorders (Timmerman et al., 2005), improving feed efficiency and weight gain (Cruywagen et al., 1996; Lesmiester et al., 2004) and improve immune system (Timmerman.et al., 2005; Sun et al., 2010; Novak et al., 2012).

Kefir is a sour, viscous, slightly carbonated and alcoholic milk beverage, which is traditionally fermented with bacteria and yeasts. Kefir is prepared by inoculating cows, sheep's or goat's milk with the kefir grains (Farnworth, 2005). It contains proteins, polysaccharides, ethyl alcohol, lactic acid, fat, minerals and vitamins
(Farnworth, 2005). Kefir grains consist of lactic acid bacteria, acetic acid bacteria such as Lactobacillus species, Lactobacillus acidophilus, Leuconostoc, Acetobacter species and Streptococcus species, yeasts as Saccharomyces and Torula and other microorganisms (Toba et al., 1990). The influence of kefir on health has been well studied in mice, rats,poultry and goat kids (Çevikbaş et al., 1994; Thoreux and Schucker, 2001; Atasoglu et al., 2010; Toghyani et al., 2015 ). However, researches on usage of kefir in calves are rather limited. The aim of this study was to investigate the effect of kefir as a probiotic on the performance of young dairy calves. The present study aimed at investigating the efficacy of kefir as a probiotic source in female calves.

\section{Materials and Methods}

The experiment was carried out in August-September. The experiment was conducted in a commercial dairy farm (İtimat Süt ve Süt Ürünleri Çiftliği-Bursa, Turkey).

The management of calves and all procedures in the present study were performed according to the Animal Experimental Guidelines for Uludağ University Local Ethical Committee.

Animals, Diets, and Experimental Design

Thirty Holstein female calves (initial body weight $=40.53 \mathrm{~kg}$ ) were assigned randomly at 3 -day-old to one of three treatments. Treatments included: no probiotic supplementation (control), commercial probiotic (3 
$\mathrm{g} / \mathrm{d} /$ calf bacteria-based and $2 \mathrm{~g} / \mathrm{d} /$ calf yeast-based), kefir $(20 \mathrm{ml} / \mathrm{d} / \mathrm{calf})$. The bacteria-based probiotic powder contains a mixture of Lactobacillus plantarum, $L$. delbrueckii, L. acidophilus, L. rhamnosus, Bifidobacterium bifidum, Streptococcus salivarius, Enterococcus faecium $\left(2 \times 10^{11} \mathrm{cfu} / \mathrm{g}\right)$ and the yeast-based probiotic powder contains Saccharomyces cerevisiae strain NCYC Sc47 $\left(1 \times 10^{10} \mathrm{cfu} / \mathrm{g}\right)$. Kefir was in a liquid form with a microbial composition of Lactococcus spp. $\left(3.2 \times 10^{8} \mathrm{cfu} / \mathrm{mL}\right)$, Lactobacillus spp. $\left(1.1 \times 10^{8} \mathrm{cfu} / \mathrm{mL}\right)$ and yeast $\left(5.9 \times 10^{3} \mathrm{cfu} / \mathrm{mL}\right)$ (Anonymous, 2004). Calves were housed individually in calf house with separated pens of $1.5 \mathrm{~m}$ (length) x $1.2 \mathrm{~m}$ (width), each of which was equipped with feeding and watering trough as required for calves. All pens were located in the same calf house and the calves were randomly allocated. There were two empty pens left between the groups to minimize the possible group effect (contamination by spores). The calf house was equipped with controlled ventilation and the bedding in the pens was chopped straw. Manure was removed daily and chopped straw was given to all pens again. Calves fed $2 \mathrm{~L}$ of fresh colostrum by nipple bottle at birth, and again after $4 \mathrm{~h}$, and every $12 \mathrm{~h}$ thereafter. Calves were fed colostrums for $3 \mathrm{~d}$ then switched to milk until weaning ( 8 weeks). All calves received $4.5 \mathrm{~kg}$ whole milk which divided into two equal portions and fed at 0800 and $1600 \mathrm{~h}$. Doses of kefir and commercial probiotic were chosen on the basis of results of other studies (Cruywagen et al., 1996; Timmerman et al., 2005; Atasoglu et al. 2010). Kefir was given orally using a sterile syringe before feeding each morning. Commercial probiotic ( $3 \mathrm{~g} / \mathrm{d} / \mathrm{calf}$ bacteria-based and $2 \mathrm{~g} / \mathrm{d} / \mathrm{calf}$ yeastbased) was resuspended in $20 \mathrm{~mL}$ distilled water and given daily in the same way as kefir. A calf starter was individually offered for ad libitum from $14 \mathrm{~d}$ of age. Calf starter was pelleted (diameter of $3 \mathrm{~mm}$ ) and contained no growth promoters. The composition and the analyzed nutrient content of offered feeds are provided in Table 1. Calves were weaned when they started to consume $0.8 \mathrm{~kg}$ of calf starter per day for three consecutive days (at 56 days of age). The experiment was performed in 70 days. Starter intake as air-dry matter and fecal consistency scoring were measured daily. Fecal samples were collected and analysed on days of 14 and 28. Calves were weighted every two weeks.

\section{Sampling, Measurement and Analyses}

The dry matter and $\mathrm{N}$ analysis were determined in the calf starter (AOAC, 1995), as well as neutral detergent fiber (NDF) and acid detergent fiber (ADF) (Van Soest et al., 1991). The NDF was analysed with addition of a heat stable alpha-amylase and without sodium sulphite. The $\mathrm{NDF}$ and ADF contents are expressed inclusive of residual ash. On the test days during the suckling period, the analysis for dry matter, solids-not-fat, fat, protein and lactose of the milk samples was carried out using an autoanalyzer.

Fecal scoring of fecal fluidity, consistency, odor, and days scoured was conducted daily in the morning $(9.00$ AM). Fecal scores based on a four-point scale were recorded using the procedure of Larson et al. (1977). Scoring was as follows: for fecal fluidity, $1=$ normal, $2=$ soft, 3 = runny or $4=$ watery.

Fecal samples were collected from rectum with sterile rubber gloves and place in sterile $50 \mathrm{~mL}$ plastic tubes. The samples were transported to the laboratory. The samples were stored in a freezer at $-20^{\circ} \mathrm{C}$ until analysis for counts of lactobacilli and coliforms. A subsample (1 $\mathrm{g}$ ) of the feces was placed in a $50 \mathrm{~mL}$ falcon tube and mixed with $9 \mathrm{~mL}$ of distilled water. The mixture was vortexed. Bacterial enumeration was carried out using selective growth media and growth conditions. Fecal subsamples $(1 \mathrm{~g})$ were serially diluted with $9 \mathrm{~mL}$ of sterilized saline water dilution from $10^{-1}$ to $10^{-8}$. From each dilution, $100 \mu \mathrm{l}$ of suspension was plated out, in triplicate on the MRS agar (Merck, Darmstadt, Germany) and eosin methylene blue agar (Oxoid) for the determination of the total cell count of Lactobacillus spp. and coliforms, respectively. The MRS broth agar plates were incubated anaerobically at $37^{\circ} \mathrm{C}$ for $24 \mathrm{~h}$. Eosin methylene blue agar plates were incubated an anaerobic condition at $37^{\circ} \mathrm{C}$ for $48 \mathrm{~h}$. After incubation, viable bacterial colonies on each medium were counted. The total cell counts of lactobacilli and coliforms per gram of fecal material were calculated. Numbers of colony forming unit (CFU) were expressed as $\log _{10} \mathrm{CFU} / \mathrm{g}$ feces.

Table 1 The composition of fresh milk and calf starter

\begin{tabular}{|c|c|c|}
\hline Ingredients & Calf starter & Fresh milk \\
\hline Maize & 410 & \\
\hline Dried distillers grains with solubles & 100 & \\
\hline Wheat shorts & 158 & \\
\hline Molasses & 50 & \\
\hline Soyabean meal & 237 & \\
\hline Salt & 5 & \\
\hline Vitamin-mineral premix $*$ & 25 & \\
\hline Limestone & 15 & \\
\hline \multicolumn{3}{|c|}{ Analysed content $(\mathrm{g} / \mathrm{kg})$} \\
\hline Dry matter & 897.2 & 83.0 \\
\hline Crude protein & 184.4 & 30.3 \\
\hline Fat & 49.6 & 35.0 \\
\hline Neutral detergent fiber & 156.4 & - \\
\hline Acid detergent fiber & 43.4 & - \\
\hline
\end{tabular}




\section{Statistical Analysis}

Results were subjected to analyses of variance, and the means were separated by Duncan's (1955) multiple range test. Means were considered significantly different at $\mathrm{P}<0.05$ (Minitab, 2000). The mathematical model used was as the following:

$$
Y i j=\mu+a i+b j+e i j
$$

where $Y i j$ is the individual observation, $\mu$ is experimental mean, $a i$ is treatment effect, $b j$ is replication effect, and eij is the error term.

\section{Results and Discussion}

Effects of dietary treatments on growth performance in female calves were presented in Table 2. Supplementation of different probiotic sources did not influence $(\mathrm{P}>0.05)$ weaning and final body weight. Supplementation of different probiotic sources did not influence weaning and final body weight $(\mathrm{P}>0.05)$. Reports on probiotic supplementation for calves have different results with respect to growing performance. Previous some papers reported beneficial effects of probiotics on animal growth (Abe et al., 1995; Timmerman et al., 2005; Frizzo et al., 2010), while others (Jenny et al., 1991; Higginbotham and Bath, 1993; AbuTarboush et al., 1996; Cruywagen et al., 1996) reported no effects. This discrepancy among the different studies may be related to several factors such as age at supplementation (Cruywagen et al., 1996) and environmental factors (Krehbiel et al., 2003). In the present study, probiotic sources during 0-14 days tended to increase daily weight gain compared the control group suggesting that commercial probiotic and kefir could have beneficial effect on daily weight gain during the first weeks of life. This result could be related to the health beneficial effect of these probiotics. Additionally, this explanation is further supported by tended to the improvement in fecal scores and Lactobacillus count in the feces in calves fed different probiotics. Cruywagen et al. (1996) reported that average daily gain during week 2 was affected by $L$. acidophilus supplementation. Timmerman et al. (2005) report a clear increase in weight gain in 1 week old veal calves supplemented with probiotics but limited beneficial effects during the first 2 weeks of life. Supplementation of different probiotic sources did not affect on starter intake of calves throughout the study $(\mathrm{P}>0.05)$. Similarly, Quigly et al. (1992) found no significant effect of yeast probiotic on intake of starter in dairy calves. Abney (2001) reported no significant difference in dry matter intake between calves received probiotic and control group. In contrast, Higginbotham and Bath (1993) and Abe et al. (1995) reported positive effects on dry matter intake by feeding probiotics. Rust et al. (2000) reported increased dry matter intake in beef steers which received lactic acid based probiotic. The lack of response to probiotics in the present study was probably because of the calves were not stressed. According to Ruppert et al. (1994), when the diet was supplemented with a probiotic and when calves were kept under stressful conditions, feed intake of calves (2 to $28 \mathrm{~d})$ was higher than intake for calves in the negative control group. In the present study, probiotic sources during 0-14 days tended to increase weight gain without changes in starter intake suggesting that probiotic sources may have positive effects on feed efficiency. Previous some studies (Cruywagen et al., 1996; Lesmeister et al., 2004; Frizzo et al., 2008) also reported improvement in utilization of feed with probiotics.

Table 2 Growth performance of calves fed different probiotics.

\begin{tabular}{|c|c|c|c|c|c|}
\hline Parameter & Control & Commercial Probiotic * & Kefir** & SEM & $\mathrm{P}$ \\
\hline \multicolumn{6}{|c|}{ Body weight, kg } \\
\hline Initial & 40.29 & 40.36 & 40.23 & 0.96 & 0.99 \\
\hline Weaning & 67.96 & 69.16 & 68.40 & 1.16 & 0.76 \\
\hline Final & 78.14 & 79.74 & 78.87 & 1.25 & 0.66 \\
\hline \multicolumn{6}{|c|}{ Daily weight gain, g/day } \\
\hline \multicolumn{6}{|l|}{ Pre-Weaning } \\
\hline 0-14 days & 272.1 & 365.0 & 342.1 & 29.87 & 0.09 \\
\hline 14-28 days & 506.4 & 471.4 & 461.4 & 32.96 & 0.61 \\
\hline $28-42$ days & 552.9 & 555.7 & 573.6 & 15.55 & 0.60 \\
\hline 42-56 days & 645.0 & 665.0 & 635.0 & 15.09 & 0.37 \\
\hline \multicolumn{6}{|l|}{ Post-Weaning } \\
\hline 56-70 days & 727.1 & 755.7 & 747.8 & 22.15 & 0.64 \\
\hline $0-70$ days & 530.7 & 562.6 & 552.0 & 22.51 & 0.59 \\
\hline \multicolumn{6}{|c|}{ Starter intake, g/day } \\
\hline \multicolumn{6}{|l|}{ Pre-Weaning } \\
\hline 14-28 days & 257.8 & 264.7 & 259.9 & 3.33 & 0.34 \\
\hline $28-42$ days & 475.3 & 479.6 & 474.3 & 3.71 & 0.56 \\
\hline 42-56 days & 668.7 & 685.2 & 665.7 & 8.47 & 0.23 \\
\hline \multicolumn{6}{|l|}{ Post-Weaning } \\
\hline 56-70 days & 907.1 & 921.7 & 897.3 & 12.95 & 0.42 \\
\hline $0-70$ days & 577.3 & 587.8 & 574.3 & 38.54 & 0.96 \\
\hline
\end{tabular}


Table 3 Fecal consistency scores and microbial counts in feces of calves fed different probiotics.

\begin{tabular}{|c|c|c|c|c|c|}
\hline Parameter & Control & Commercial Probiotic $*$ & Kefir** & SEM & $\mathrm{P}$ value \\
\hline \multicolumn{6}{|c|}{ Fecal consistency score $* * *$} \\
\hline \multicolumn{6}{|l|}{ Pre-Weaning } \\
\hline 0-14 days & 2.32 & 2.20 & 2.22 & 0.046 & 0.14 \\
\hline 14-28 days & 2.03 & 1.91 & 1.96 & 0.051 & 0.25 \\
\hline 28-56 days & 1.66 & 1.63 & 1.60 & 0.034 & 0.45 \\
\hline \multicolumn{6}{|l|}{ Post-Weaning } \\
\hline 56-70 days & 1.52 & 1.54 & 1.56 & 0.042 & 0.77 \\
\hline 0-70 days & 1.84 & 1.78 & 1.79 & 0.024 & 0.18 \\
\hline \multicolumn{6}{|c|}{ Coliform, $\left(\log _{10}\right.$ of count/g of feces) } \\
\hline 14 days & 6.84 & 6.24 & 6.35 & 0.30 & 0.35 \\
\hline 28 days & 6.45 & 6.17 & 6.09 & 0.29 & 0.66 \\
\hline Average & 6.64 & 6.21 & 6.22 & 0.20 & 0.24 \\
\hline \multicolumn{6}{|c|}{ Lactobacilli, $\left(\log _{10}\right.$ of count/g of feces) } \\
\hline 14 days & 6.83 & 7.60 & 7.76 & 0.30 & 0.09 \\
\hline 28 days & 6.55 & 7.35 & 7.03 & 0.31 & 0.22 \\
\hline Average & $6.67^{\mathrm{a}}$ & $7.48^{\mathrm{b}}$ & $7.40^{\mathrm{ab}}$ & 0.22 & 0.03 \\
\hline
\end{tabular}

* Commercial probiotic ( $3 \mathrm{~g} / \mathrm{d} /$ calf bacteria-based and $2 \mathrm{~g} / \mathrm{d} /$ calf yeast-based) **kefir (20 ml/d/calf), *** Faecal consistency score 1-normal 2- soft; 3runny; 4- watery, ${ }^{\text {ab }}$ Differences in superscript indicate significance at $\mathrm{P}<0.05$.

Effects of dietary treatments on fecal consistency scores and microbial counts in feces of calves fed different probiotics in female calves were presented in Table 3. Different probiotic sources did not affect $(\mathrm{P}>0.05)$ on faecal consistency scores of calves throughout the study. However, probiotic treatments tended $(\mathrm{P}<0.14)$ to lower fecal score during $0-14$ days compared to the control. Abu-Tarboush et al. (1996) also reported that calves fed L. acidophilus $27 \mathrm{SC}$ had a significantly lower scour index compare with calves fed the control diet. Magalhaes et al. (2008) used yeast culture and reported improvement in fecal scores in calves. In contrast, Cruywagen et al. (1996) reported no positive effects on general health by feeding probiotics. In the present study, although on 14 and 28 days the fecal populations of coliform bacteria were no different ( $P>0.05)$ among the treatments; there were a tendency to increase in fecal populations of lactobacilli by probiotic treatments at d 14. Also, commercial probiotic treatment increased the average fecal population of lactobacilli compared to the control. On the other hand, kefir tended to increase the average fecal population of lactobacilli. Increases in fecal lactobacilli with probiotic supplementation have been also reported by many researchers (Ellinger et al., 1980; Jenny et al., 1991; AbuTarboush et al., 1996). Gilliland et al. (1980) fed L.acidophilus isolated from a human and calf intestinal tract to newborn calves and observed an increase in facultative lactobacilli in the feces during 0-14 days. The mechanism of action of probiotics is still debated, but generally, it is related to function by maintaining the presence of beneficial microorganisms in the gut by the competitive exclusion of pathogenic bacteria adherence (Riddell et al., 2010). In this way probiotics can influence the intestinal microbiota as well as host health, also increasing nutrient utilization, producing bacteriocins and stimulating the immune system (Corcionivoschi et al., 2010).

\section{Conclusion}

Kefir may offer a great potential as a probiotic source for investigation in animal production since it is natural, cheap and easy to be produced on the farm. Results from this study showed that although kefir feeding had no effects on weaning and final body weight, starter intake and overall fecal score, it tended to improve daily weight gain, fecal score and in lactobacilli count in the feces during 0-14 days. Kefir as a probiotic may be improving daily weight gain and health status of calves particularly during the early stage of life. A further study is needed to prove the efficacy of using kefir in commercial farms on a larger scale.

\section{Acknowledgements}

This study was a part of MSc by S. Satık and supported by the Scientific Research Project Committee of Süleyman Demirel University, Turkey

\section{References}

Abe F, Ishibashi N, Shimamura S. 1995. Effect of administration of bifidobacteria and lactic acid bacteria to newborn calves and piglets. Journal of Dairy Science, 78,2838-2846.

Abney MD. 2001. Effects of feeding direct-fed microbials and prebiotics on receiving calf performance, health, and fecal shedding of pathogens. M.S Thesis: Texas Tech University.Texas

Abu-Tarboush HM, Al-Saiady MY, Keir El-Din AH. 1996. Evaluation of diet containing lactobacilli on performance, fecal coliform, and lactobacilli of young dairy calves. Animal Feed Science and Technology, 57, 39-49.

Anonymous 2004. Report on chemical and microbial composition of kefir. TUBITAK Marmara Res. Center, Adapazarı, Turkey.

AOAC (Association of Official Analytical Chemists). 1995. Official Methods of Analysis, 16th ed. Arlington, VA, USA.

Atasoglu C, Akbag HI, Tolu C, Das G, Savas T, Yurtman IY. 2010. Effects of kefir as a probiotic source on the performance of goat kids. South African Journal of Animal Science, 40,363-370. 
Corcionivoschi N, Drinceanu D, Pop I, Stack M, Stef D, Julean L. 2010. The effect of probiotics on animal health. Journal of Animal Science and Biotechnology, 43, 35-41.

Cruywagen CW. Jordaan I, Venter L. 1996. Effect of Lactobacillus acidophillus supplementation of milk replacer on preweaning performance of calves. Journal of Dairy Science, 79, 483-486.

Çevikbaş A, Yeni E, Ezzedenn FW, Yardımcı T, Çevikbaş U, Stohs SJ. 1994. Antitumoral, antibacterial and antifungal activities of kefir and kefir grain. Phytotherapy Research, 8: 78-82.

Duncan DB. 1955. Multiple range and multiple F tests. Biometrics 11: $1-42$.

Ellinger DK, Muller LD, Glantz PJ. 1980. Influence of feeding fermented colostrum and Lactobacillus acidophilus on fecal flora of dairy calves. Journal of Dairy Science, 63, 478-482.

Farnworth ER. 2005. Kefir - a complex probiotic. Food Science and Technology Bulletin, 2 (1): 1-17.

Frizzo LS, Bertozzi E, Soto LP, Zbrun MV, Sequeira G, Santina RD, Rodriguez AR, Rosmini MR. 2008. The effect of supplementation with three lactic acid bacteria from bovine origin on growth performance and health status of young calves. Journal of Animal and Veterinary Advances, 7, 400-408.

Frizzo LS, Soto LP, Zbrun MV, Bertozzi E, Sequeira G, Rodríguez Armesto R, Rosmini M.R. 2010. Lactic acid bacteria to improve growth performance in young calves fed milk replacer and spray-dried whey powder. Animal Feed Science and Technology, 157, 159-167.

Fuller R. 1989. A review: Probiotics in man and animals. Journal of Applied Bacteriology. 66: 365-378.

Gilliland SE, Bruce BB, Bush LJ, Staley TE. 1980. Comparison of two strains of Lactobacillus acidophilus as dietary adjuncts for young calves. Journal of Dairy Science, 63: 64-972.

Higginbotham GE, Bath DL. 1993. Evaluation of Lactobacillus fermentation cultures in calf feeding systems. Journal of Dairy Science, 76: 615-620.

Jenny BF, Vandkijk HJ, Collins JA. 1991. Performance and fecal flora of calves fed a Bacillus subtilis concentrate. Journal of Dairy Science, 74: 1968-1973.

Krehbiel CR, Rust SR, Zhang G, Gilliland SE. 2003. Bacterial direct-fed microbials in ruminant diets: Performance response and mode of action. Journal of Animal Science, 81: E120-E132.

Larson LL, Owens FG, Albright JL, Appleman RD, Lamb RC, Muller LD. 1977. Guidelines toward more uniformity in measuring and reporting calf experimental data. Journal of Dairy Science, 60: 989-991.

Lesmeister KE, Heinrichs AJ, Gabier MT. 2004. Effects of supplemental yeast culture on rumen development, growth character and blood parameters in neonatal dairy calves. Journal of Dairy Science, 87: 1832-1839.
Magalhães VJ, Susca F, Lima FS, Branco AF, Yoon I, Santos JEP. 2008. Effect of feeding yeast culture on performance, health, and immunocompetence of dairy calves. Journal of Dairy Science 91: 1497-1509.

Minitab. 2000. Minitab Reference Manuel (release 13.0). Minitab, State College, PA, USA.

Novak KN, Davis E, Wehnes CA, Shields DR, Coalson JA, Smith AH, Rehberger TG. 2012. Effect of supplementation with an electrolyte containing a Bacillus-based direct-fed microbial on immune development in dairy calves. Research in Veterinary Science, 92: 427-434.

Quigley JDL, Wallis B, Downlow H, Heitman RN. 1992. Sodium bicarbonate and yeast culture effects on ruminal fermentation, growth and intake in dairy calves. Journal of Dairy Science, 75: 3531-3538.

Radostits OM. 1975. Treatment and control of neonatal diarrhea in calves. Journal of Dairy Science, 58: 464-470.

Riddell JB, Gallegos AJ, Harmon DL, Mcleod KR. 2010. Addition of a bacillus based probitic to the diet of preruminant calves: influence on growth, health, and blood parameters. International Journal of Applied Research in Veterinary Medicine, 8: 78-85.

Ruppert LD, McCoy GC, Hutjens MF. 1994. Feeding of probiotics to calves. Journal of Dairy Science, 77(Suppl. 1): 296.

Russell JB, Houlihan AJ. 2003. Ionophore resistance of ruminal bacteria and its potential impact on human health. FEMS Microbiology Reviews, 27: 65-74.

Rust SR, Metz K, Ware DR. 2000. Effects of Bovamine ${ }^{\text {TM }}$ rumen culture on the performance and carcass characteristics of feedlot steers. Journal of Animal Science 78, (Supp2): 83.

Sun P, Wang JQ, Zhang HT. 2010. Effects of Bacillus subtilis natto on performance and immune function of preweaning calves. Journal of Dairy Science, 93: 5851-5855.

Thoreux K, Schmucker DL. 2001. Kefir milk enhances intestinal immunity in young but not old rats. Journal of Nutrition, 131: 807-812.

Timmerman HM, Mudler L, Everts H, Vanespan DC. 2005. Health and growth of veal calves fed milk replacer with or without probiotics. Journal of Dairy Science 75: 894-899.

Toba T, Arihara K, Adachi S. 1990. Distribution of microorganisms with particular reference to encapsulated bacteria in kefir grains, International Journal of Food Microbiology, 10: 219-224.

Toghyani M, Kazem Mosavi S, Modaresi M, Landy N. 2015. Evaluation of kefir as a potential probiotic on growth performance, serum biochemistry and immune responses in broiler chicks. Animal Nutrition 1(4): 305-309.

Van Soest PJ, Robertson JB, Lewis BA. 1991. Methods for dietary fiber neutral detergent fiber and nonstarch polysaccharides in relation to animal nutrition. Journal of Dairy Science, 74: 35833597. 